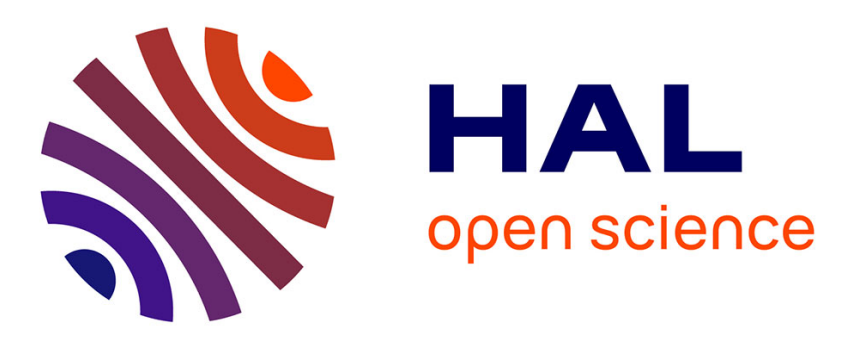

\title{
Duration of passive and active phases of the second stage of labour and risk of severe postpartum haemorrhage in low-risk nulliparous women.
}

\author{
Camille Le Ray, William Fraser, Patrick Rozenberg, Bruno Langer, Damien \\ Subtil, François Goffinet
}

\section{To cite this version:}

Camille Le Ray, William Fraser, Patrick Rozenberg, Bruno Langer, Damien Subtil, et al.. Duration of passive and active phases of the second stage of labour and risk of severe postpartum haemorrhage in low-risk nulliparous women.: duration of active second stage of labour and postpartum haemorrhage. European Journal of Obstetrics \& Gynecology and Reproductive Biology, 2011, 158 (2), pp.167-172. 10.1016/j.ejogrb.2011.04.035 . inserm-00614239

\section{HAL Id: inserm-00614239 https://www.hal.inserm.fr/inserm-00614239}

Submitted on 10 Aug 2011

HAL is a multi-disciplinary open access archive for the deposit and dissemination of scientific research documents, whether they are published or not. The documents may come from teaching and research institutions in France or abroad, or from public or private research centers.
L'archive ouverte pluridisciplinaire HAL, est destinée au dépôt et à la diffusion de documents scientifiques de niveau recherche, publiés ou non, émanant des établissements d'enseignement et de recherche français ou étrangers, des laboratoires publics ou privés. 


\section{Duration of passive and active phases of the second stage of labour and risk of severe}

postpartum haemorrhage in low-risk nulliparous women

C. Le Ray (1, 2), W. Fraser (3), P. Rozenberg (4), B. Langer (5), D. Subtil (6), F. Goffinet (1,

2) (for the PREMODA Study group)

(1) INSERM Unit 953 (ex-U149), Epidemiological Research Unit on Perinatal Health and Women's Health, Paris, France

(2) Maternité Port Royal, Hôpital Cochin Saint-Vincent-de-Paul, Assistance Publique Hôpitaux de Paris, Université Paris-Descartes, France

(3) Sainte Justine Hospital, Department of Obstetrics and Gynecology, University of Montréal, Montréal QC, Canada

(4) Centre Hospitalier Intercommunal (CHI) de Poissy-Saint-Germain, Department of Obstetrics and Gynecology, Université Versailles-Saint-Quentin, Poissy, France

(5) Hôpital de Hautepierre, Department of Obstetrics and Gynecology, Strasbourg, France

(6) Hôpital Jeanne-de-Flandre, Department of Obstetrics and Gynecology, Centre Hospitalier Régional et Universitaire de Lille, Lille, France

\section{Corresponding author:}

Camille LE RAY, MD, PhD

INSERM U953, Epidemiological Research Unit on Perinatal Health and Women's Health

82 Avenue Denfert-Rochereau, 75014 Paris, France

Tel: $33142345570 / 33142345580$

Fax: 33143268979

Email: camille.le-ray@cch.aphp.fr

Running title: duration of active second stage of labour and postpartum haemorrhage

Key words: passive second stage; active second stage; nullipara; postpartum haemorrhage 


\section{Abstract:}

Objective: To assess the risk of severe postpartum haemorrhage (PPH) according to the duration of the passive and active phases of the second stage of labour

Design: Secondary analysis of the PREMODA prospective observational study

Setting: 138 French maternity units

Population: 3330 low-risk nulliparous women with vaginal deliveries of cephalic singletons

Methods: Analysis of the prospectively recorded durations of the active phase of the first stage and the passive and active phases of the second stage of labour and their association with severe PPH, defined by estimated blood loss $>1000 \mathrm{ml}$ or blood transfusion. Factors associated with severe PPH were analysed by uni- and multivariable analysis with logistic regression models.

Main outcome measures : Severe postpartum haemorrhage

Results: The frequency of severe PPH was $2.1 \%(n=69)$. In the univariable analysis, severe PPH increased with the duration of the active but not the passive second stage: $1.2 \%$ for active second stage $<10 \mathrm{~min}, 1.6 \%$ for $10-19 \mathrm{~min}, 2.1 \%$ for $20-29 \mathrm{~min}, 2.6 \%$ for $30-39 \mathrm{~min}$, $4.5 \%$ for $40-49 \min$ and $14.3 \%$ for $\geq 50 \min (p<0.001)$. After adjustment for confounding factors, the risk of severe PPH was statistically significant when the active first stage exceeded 6 hours (adjusted OR=2.5[1.0-6.1]) and when pushing lasted longer than 40 minutes (40-49 min: adjusted $\mathrm{OR}=3.5[1.0-12.3], \geq 50 \mathrm{~min}$ : adjusted $\mathrm{OR}=10.6[2.8-40.3]$, reference: $<10 \mathrm{~min})$. The duration of expulsive efforts was not associated with other maternal or neonatal complications.

Conclusion: A prolonged active — but not passive — second stage is associated with the risk of severe PPH in nulliparas. The optimal duration of these phases remains to be defined. 


\section{$\underline{\text { Introduction }}$}

Many authors report that a prolonged second stage is associated with maternal complications, especially postpartum haemorrhage (PPH) related to uterine atony (1-7). They studied the second stage of labour, beginning at full dilatation and finishing at birth, as an only one continuous phase. However, the second stage is divided into two phases: the passive second stage, during which the fetal head descends passively down the maternal pelvis, and the active second stage, which corresponds to the phase of pushing expulsive efforts. The physiology of the two phases differs, as demonstrated by Buhimschi et al., who found that women in labour increase their intrauterine pressure $62 \%$ by actively pushing with a contraction during the second stage (8). Studying the two phases separately might make it possible to determine which — passive or active or both — increases maternal complications, especially the risk of severe PPH. This finding could have important clinical implications, favouring the practice of either early or delayed pushing, or limiting the duration of expulsive efforts. In a recent publication from a secondary analysis of the PEOPLE trial, we found an increased maternal risk of PPH after 2 hours of active second-stage labour (9). That study did not, however, take in account the relation between PPH and duration of the passive second stage.

The objective of our study was to analyse maternal consequences, especially severe PPH, according to durations of the passive and active phases of the second stage of labour, in lowrisk nulliparous women. 


\section{$\underline{\text { Methods }}$}

The PREMODA study was a prospective observational study of the delivery of term breech infants, conducted, between 1 June 2001 and 31 May 2002, in 138 French maternity units (more than one fifth of all French maternity units) (10). The study was approved by the National Data Protection Authority in Paris (on 9 May 2001). The control group included 9962 singleton pregnancies in cephalic presentation at more than 37 weeks, specifically, those in the same units over the same period who were assigned a delivery record number that was a multiple of 20. This procedure provided a random selection of $5 \%$ of all the singleton cephalic term births. This study was based on prospective data rigorously collected from a questionnaire specifically designed to assess management of labour and delivery, neonatal health status and maternal complications.

For our study, we conducted a secondary analysis of a population of low-risk nulliparas from the PREMODA study control group. This population of low-risk nulliparas was defined by the following criteria: nulliparous women with a singleton fetus in cephalic presentation at term (gestational age $\geq 37$ weeks) $(n=4218)$, as used in other secondary analysis of PREMODA study $(11,12)$. Women with caesarean delivery before $(\mathrm{n}=101)$ and during labour $(n=460)$, induction of labour for maternal $(n=159)$ or fetal $(n=116)$ disorders, and congenital malformations $(\mathrm{n}=60)$ were excluded.

The duration of each stage of labour was prospectively collected, together with maternal (age and place of birth) and neonatal (gestational age and birth weight) characteristics and obstetric practices (elective induction of labour, oxytocin during labour and operative vaginal delivery). The main outcome criterion was severe PPH, defined by an estimated blood loss exceeding 
$1000 \mathrm{ml}$ or blood transfusion in the first 24 hours after delivery. Because measurement of moderate PPH is so subjective, we did not record this outcome. Other maternal outcomes studied were third- and fourth- degree perineal tears and postpartum maternal fever > 48 hours or endometritis before discharge. Neonatal outcomes studied were: neonatal asphyxia defined by $\mathrm{pH} \leq 7.10$ or 5 -minute Apgar score $\leq 7$ and neonatal morbidity defined by any adverse neonatal outcome (arterial $\mathrm{pH}$ at birth $\leq 7.10$ or 5 -minute Apgar score $\leq 7$ or neonatal trauma or NICU admission).

We analysed risk of severe PPH according to duration of each stage or phase of labour, beginning with the active phase of the first stage (excluding the early labour phase), and including the passive and active second stages. About duration of the active second stage, the French College of Obstetricians and Gynaecologists (CNGOF) recommends considering an assisted delivery after 30 minutes of expulsive efforts (13). Although these guidelines date only from 2007 and the level of evidence for this recommendation is low (grade C) (14), this has been standard practice in France for a long time (15). There is no specific recommendation about optimal duration of the passive second stage.

The duration of the active first stage, i.e., from 5 to $10 \mathrm{~cm}$ dilatation, was categorised in twohour intervals. The duration of the passive second stage, i.e., duration of labour between $10 \mathrm{~cm}$ (full dilatation) and the beginning of expulsive efforts, was divided into three classes (less than $1 \mathrm{~h}$, from 1 to $2 \mathrm{~h}$ and more than $2 \mathrm{~h}$ ). The duration of the active second stage, i.e., of pushing, was categorised into six classes: 0-9 minutes (min), 10-19 min, 20-29 min, 30-39 min, 40-49 $\min$ and $\geq 50$ min. We determined the factors associated with severe PPH, the duration of each stage of labour, neonatal and obstetric factors (gestational age, birth weight, mode of onset of labour and mode of delivery), and their associations with one another. 
Statistical analysis used Stata 10.0 software. We used the Chi-square test to compare proportions, and Fisher's exact test when the population size was small $(n<5)$. We used the Mann-Whitney test to compare median durations for each stage of labour. When a variable was missing more than $5 \%$ of data we created a specific class for missing data.

For the univariable analysis, we calculated the crude odds ratios and 95\% confidence intervals of neonatal and obstetric factors that might be associated with severe $\mathrm{PPH}$, including the duration of each stage of labour. To adjust for confounding factors in the multivariable analysis, we used an unconditional logistic regression model that included factors significant in the univariable analysis with $\mathrm{p}<0.2$. Classes with the lowest severe PPH rate were chosen as the references. 


\section{$\underline{\text { Results }}$}

Nulliparas accounted for $42.3 \%(n=4218 / 9962)$ of the PREMODA study control group. Among them, $78.9 \%(n=3330 / 4218)$ were at low risk according to the inclusion and exclusion criteria. Table 1 describes the characteristics, obstetric practices and maternal and neonatal outcomes for this study population. In all, 69 (2.1\%) of them had severe PPH, but only two were admitted to a maternal intensive care unit.

Data about duration of expulsive efforts were available in $3258(97.8 \%)$ cases. Consistent with standard French practices and guidelines, the median duration of pushing was 15 minutes (interquartile interval: 10-25 minutes). However, 602 (18.5\%) women had an active second stage longer than 30 minutes. Table 2 compares the duration of each stage of labour for the groups with and without severe PPH. The median duration of the active first stage and the passive second stage were similar in the severe $\mathrm{PPH}$ and control groups, respectively, 2.5 hours versus 2.7 hours $(\mathrm{p}=0.279)$ and 30 minutes for both groups $(\mathrm{p}=0.391)$. The median duration of the active second stage, however, was significantly longer in the severe PPH group compared with the control group (20 minutes versus 15 minutes, $\mathrm{p}<0.001$ ).

The rate of assisted vaginal delivery was $24.0 \%(n=801)$ and increased with duration of expulsive efforts (<10 min: $12.4 \%, 10-19 \min : 18.1 \%$; $20-29 \min : 26.2 \%, 30-39 \min : 39.4 \%$, 40-49 min: $52.2 \%, \geq 50 \min : 50 \%, \mathrm{p}<0.001)$. The relationship between assisted vaginal delivery and severe PPH was not significant (1.9\% of the spontaneous vaginal deliveries had severe PPH versus $2.8 \%$ for assisted deliveries, $\mathrm{p}=0.124$ ). Table 3 summarises the results for the association between severe PPH and duration of the active second stage according to type of vaginal delivery. The association between severe $\mathrm{PPH}$ and the duration of the active second 
stage then remained significant only among women with assisted vaginal deliveries $(\mathrm{p}=0.006)$; it was no longer significant for spontaneous deliveries $(\mathrm{p}=0.093)$ (Table 3$)$.

In the multivariable analysis, the duration of the active first stage was associated with the risk of severe PPH (active first stage $>6$ hours: adjusted OR=2.5 [1.0-6.1], reference: interval 2$4 \mathrm{~h}$ ) (Table 4). We found no association between the duration of the passive second stage and the risk of PPH (for passive second stage longer than 2 hours: crude $\mathrm{OR}=1.2,95 \% \mathrm{CI}$ [0.52.9], reference: passive second stage less than 1 hour). The risk of severe PPH increased significantly with the duration of expulsive efforts. Odds ratios of severe $\mathrm{PPH}$ reached a significant level after 40 minutes of pushing (interval 40-49 min: adjusted $\mathrm{OR}=3.5$ [1.0-12.3], $\geq 50$ min: adjusted $\mathrm{OR}=10.6$ [2.8-40.3], reference: $<10 \mathrm{~min}$ ) (Table 4). When the duration of the active second stage was treated dichotomously in two classes (up to and after 30 minutes), the risk of severe PPH was significantly higher after 30 minutes (crude OR=2.3 [1.4-3.8] and adjusted $\mathrm{OR}=2.0[1.1-3.5])$.

The risks of third or fourth degree perineal tears, of postpartum maternal fever $>48$ hours and of endometritis were not associated with the duration of active pushing in univariate analysis. We found no association between the duration of the active second stage and the risk of neonatal asphyxia or neonatal morbidity (data not shown). 


\section{$\underline{\text { Discussion }}$}

Our results show an association between the duration of the active phase of the second stage of labour and the risk of severe PPH in nulliparous women at low risk. On the contrary, however, severe PPH was not associated with the duration of the passive phase of the second stage.

Most authors who have studied the consequences of a prolonged second stage of labour have not differentiated between the passive and active phases of the second stage (1-7). Only a recent secondary analysis of the Canadian PEOPLE trial specifically assessed the impact of the duration of the active second stage on PPH risk: it reported that the risk of PPH increased among nulliparous women after 2 hours of pushing (9). That analysis, however, unlike this one, did not assess the impact of the duration of the passive second stage on PPH risk. Because the two phases of the second stage differ physiologically, prolongation of the duration of each could have different consequences. Thus, the passive and active phases should be analysed separately for assessing management of the second stage. Confirmation of our finding that $\mathrm{PPH}$ is associated with the duration of the active but not the passive second stage might allow obstetricians to adapt their management of low-risk nulliparous women, maybe to encourage delayed pushing and limit expulsive efforts.

Some randomised trials have assessed management of the passive second stage by measuring the impact of delayed pushing on the risk of PPH and found no difference between "early pushing" and "delayed pushing" groups, i.e., between women with shorter and longer periods of passive descent (16-19). In accordance with these findings, we confirmed that the duration of the passive phase of the second stage did not appear to be associated with severe PPH. 
Because French management of the active second stage is particularly short in comparison with other countries, our results can not be extrapolated. However, our results about management of the active phase of the second stage of labour can be compared with those from the PEOPLE trial (9). Despite these differences between French and Canadian obstetrical practices, we also found an association between the duration of the active second stage and PPH risk under French practices. This increases the external validity of the relation observed between the duration of the active second stage and the risk of PPH.

Because the PREMODA study was not initially designed to assess PPH (10), data were not collected about management of the third stage of labour, from delivery until expulsion of the placenta. The systematic use of uterotonic agents and the use of controlled cord traction may be confounding factors for the risk of severe PPH. Similarly, blood loss was not objectively measured in each delivery. Because moderate PPH, i.e., blood loss between 500 and $1000 \mathrm{ml}$, is so subjective, this outcome was not recorded in the PREMODA study. In view of the large sample of women included and the high number of participating maternity units, the PREMODA study scientific committee considered that severe PPH was an adequate criterion for assessing maternal morbidity. An objective measurement of blood loss with the use of blood collecting bags would certainly have been more accurate.

Moreover, analgesia used during labour was unfortunately not collected in the PREMODA study. Thus, we cannot assess relationship between epidural and severe PPH in our study. We agree that epidural analgesia could be also a confounding factor limiting interpretation of our results. Indeed this practice increases duration of labour and its association with PPH remains unclear in the literature. In France, the rate of delivery with loco-regional analgesia was very high during the study period, around $85 \%$ in nulliparous women. 
Caesarean section during the second stage of labour is associated with an increased risk of PPH $(20,21)$. The caesarean rate during the active phase of the second stage varies according to the management of this phase. The shorter the phase, the lower the risk of caesarean delivery. Delayed pushing is routine practice in France. As recommended by CNGOF to prevent expulsive efforts from exceeding 30 minutes, women do not usually begin to push until the fetal station reaches +2 or more, when fetal heart monitoring is normal. Thus, very few women had caesarean deliveries after beginning to push. Among all the PREMODA lowrisk nulliparous women, only $58(1.5 \%)$ women had a caesarean during the second stage and only $19(0.5 \%)$ during the active phase of that stage. Only one of them had a severe PPH; she had pushed 25 minutes. The difficulty of analysing the impact of the duration of each phase of the second stage on the risk of severe PPH among women with caesarean sections during the passive or active phase led us to exclude women with caesareans during the second stage. Moreover, in view of the very few patients who had severe PPH after a caesarean during the active second stage, we do not think that this choice modifies our results.

In accordance with national guidelines, most French obstetricians performed operative vaginal deliveries after 30 minutes of pushing, even when the fetal heart rate (FHR) monitoring was reassuring. This probably explains at least in part the higher rate of such deliveries in France (11.1\% in 2003) compared with the US $(6.6 \%$ in 2006) $(22,23)$. Previous studies have reported an association between PPH and operative vaginal delivery (24). We did not observe such an association, perhaps due to a lack of power. Cervical and vaginal lacerations due to instrumental extractions are a potential cause of PPH. Because the rate of operative vaginal delivery increased with the duration of expulsive efforts and this type of delivery may be a confounding factor, we secondly decided to stratify for it. After stratification, the risk of severe PPH among women with operative vaginal deliveries still increased with the duration 
of the active second stage. The increase in operative vaginal deliveries with duration of pushing therefore does not explain the association between severe $\mathrm{PPH}$ and the duration of expulsive efforts.

Nonetheless, our results do not allow us to conclude that severe PPH is reduced by the current French recommendations to limit pushing to 30 minutes. A policy of operative vaginal delivery after 30 minutes of pushing may indeed decrease severe PPH related to uterine atony. However, this policy may also increase the risk of PPH related to cervical and vaginal lacerations, secondary to instrumental extractions.

\section{$\underline{\text { Conclusion }}$}

Prolongation of the active but not the passive phase of the second stage of labour could be associated with an increased risk of severe PPH. These results may have important implications for second-stage management and may lead obstetricians to encourage delay in pushing and to limit the duration of expulsive efforts. The optimal duration of these phases remains to be defined, however. 
Acknowledgments :

None

\section{$\underline{\text { Disclosure of interest }}$}

There are no conflicts of interest

\section{Contribution to authorship}

CLR conducted the analyses.

FG coordinated and supervised the study.

CLR, WF and FG wrote the paper.

All authors have seen and approved the final version of the manuscript.

Details of ethics approval :

Procedures of the study received ethics approval from the National Data Protection Authority in Paris (on 9 May 2001).

\section{Funding}

This study was mainly supported by two grants from the Ministry of Health (AOM01123 (PH-RC 2001) and AOM03040 (PH-RC 2003)). It was also partly funded by the French College of Gynecologists and Obstetricians, the French Society of Perinatal Medicine and the Belgian National Funds for Scientific Research.

The funding sources had no role in the study design, data collection, data interpretation or the writing of the report. 
$\underline{\text { Scientific committee }}$

\section{F. Goffinet (INSERM U953- exU149, Port Royal Maternity, Paris, France), S. Alexander}

(School of Public Health School, Brussels, Belgium), J.M. Foidart (La Citadelle Hospital,

Liège, Belgium), S. Uzan (Tenon Hospital, Paris, France), D. Subtil (Jeanne de Flandre

Hospital, Lille, France), G. Bréart (INSERM U953- exU149, Paris France)

\section{$\underline{\text { List of } 138 \text { maternity units participating in PREMODA Study }}$}

Région Alsace: Coordinator: Pr Langer: CHU de Strasbourg (Pr Langer), CMCO de Schiltigheim (Dr Vayssiere), CHR de Haguenau (Dr Lehmann),CMC de Colmar (Dr Kutnahorsky), CHR de Mulhouse (Dr Wiedemann), Clinique Sainte Anne, Strasbourg (Dr Jeanmougin), Clinique Diaconat, Mulhouse (Dr Blum) Basse-Normandie: Coordinator: Pr Dreyfus: CHU de Caen (Pr Dreyfus/Dr Denoual-Ziad), CH de Cherbourg (Dr Ulmann), CH de Lisieux (Dr Zerger), CH de Saint Lo (Dr Refahi), CH de Flers (Dr André), CH de la Ferté Macé (Dr Nelle) - Région Bretagne: Coordinator: Pr Grall: CHU de Brest (Pr Collet), CHU Hôtel Dieu, Rennes (Pr Poulain), CHU Hôpital Sud, Rennes (Mme Pérrigot), CH de Lorient (Dr Getin), Clinique mutualiste de la Sagesse, Rennes (Dr Aussel), CH de Saint Brieuc (Dr Giono-Renaud), CH de Saint Malo (Dr Weyl), CH de Vannes (Mme Pierson), $\mathrm{CH}$ de Cornouaille (Dr Germain) - Région Centre: Coordinator: Pr Perrotin: CHU Bretonneau, Tours (Dr Alonso), CHU Beffroi, Tours (Dr Rapp), CH de Blois (Dr Montmasson), CHR d'Orléans (Dr Ceccaldi), CHG de Chartres (Dr Guilbaud) - Région Franche-Comté: Coordinator: Pr Schaal: CHU de Besançon (Dr Riethmuller), CHG de Montbéliard (Dr Zurlinden), CHG de Belfort (Dr Terzibachian) - Région Haute-Normandie: Coordinator: Pr Verspyck: CHU de Rouen (Pr Verspyck), CH de Mont Saint Aignan (Dr Fournet), CH du Havre (Dr Degré), CH d'Elbeuf (Dr Paquet), CH de Dieppe (Dr Gandour), Clinique SaintRomain, Rouen (Dr Thobois) - Région Ile de France: Réseau Sud Ouest Francilien: Coordinator: Dr Audibert: CHU de Clamart (Dr Audibert), Clinique des Vallées, Châtenay-Malabry (Dr Proust), Clinique de Meudon la Forêt (Dr Chene), CH de Dourdan (Dr Lambert), CH Sud Francilien site d'Evry (Mme Lose), CH de Fontainebleau (Dr Fillippini), CH d'Orsay (Dr Devianne); Réseau Ile de France Port-Royal: Coordinator: Dr Harvey: CHU Cochin, Paris (Dr Kayem), CHU Saint Vincent de Paul, Paris (Pr Lepercq), CHU Saint Antoine, Paris (Pr Carbonne), CH Notre Dame de Bonsecours, Paris (Dr Grovangrandi), CHU Beaujon, Paris (Mme Grapin), CHU de Colombes (Dr Crenn-Hebert), CH de Neuilly sur Seine (Dr Galimard), CH de Saint Cloud (Mme Pecourt), Hôpital Militaire Begin, Saint Mandé (Dr Ponties), Clinique Armand Brillard, Nogent sur Marne (Dr Helvin), CH Les Diaconesses, Paris (Dr Harvey); Réseau de Poissy: Coordinator: Dr Rozenberg: CHI de Poissy-Saint Germain (Mme Bertaud); Réseau inter-maternités de Saint-Denis: Coordinator: Pr Uzan: $\mathrm{CH}$ de Bondy (Dr Seince), CHI de Montreuil (Dr Chitrit), CHI de Villepinte (Dr Debièvre), Clinique Vauban, LivryGardan (Dr Kamoun), Clinique du bois d'amour, Drancy (Dr Masson), CH de Montfermeil (Dr Ropert), CHG de Saint-Denis (Dr Ekoukou), Clinique de l'Estrée, Stains (Dr Franche); Réseau Tenon: Coordinators: Pr Uzan and Dr Berkane: CHU Tenon, Paris (Dr Berkane), CHU Bichat, Paris (Pr Mandelbrot); CHI de Créteil (Pr Haddad et Dr Touboul); $\mathrm{CH}$ de Saint Maurice (Dr Bardou) - Région Limousin: Coordinator: Pr Philippe: CH de Brive (Mme Peron), CH de Tulle (Mme Barbé), CHU de Limoges (Dr Eyraud), CH d'Ussel (Mme Leclerc) - Région Lorraine: Coordinator: Pr Boutroy, Dr Thiebaugeorges: CHU de Nancy (Dr Thiebaugeorges), CH d'Epinal (Dr Scotton), CHR Bonsecours, Metz (Dr Lemarié), CH de Thionville (Dr Szwarcberg), CH Sainte Croix, Metz (Dr Ragage), Polyclinique Majorelle, Nancy (Dr Bey), Clinique Arc en Ciel, Epinal (Dr Gaillet-Schiochet), Clinique Claude Bernard, Metz (Dr Adami) - Nord Pas de Calais: Coordinator: Pr Subtil: CH d'Arras (Mme Finet), CH de Béthune (Dr Hay), CH de Boulogne (Dr Churlet), Clinique Côte d'Opale, Saint Martin les Boulognes (Dr Renault), CH de Douai (Dr Dognin), Clinique Saint Amé, Lambre-lez-Douai (Dr Doutrelant), Clinique Villette, Dunkerque (Mme Gosselin, Mme Deroose), CH de Maubeuge (Dr Hubert), CH de Roubaix (Dr Le Goueff), CH de Seclin (Dr Biausque), CH de Valenciennes (Dr Massoni), CHU de Lille (Pr Subtil), Clinique Cotteel, Villeneuve d'Ascq (Mme Dumon) - Région Pays de Loire: Coordinator: Dr Winer: CHD La Roche sur Yon (Dr Barreteau), CH de Saint Nazaire (Dr Gerard), Clinique du jardin des plantes, Saint Nazaire (Dr Rousseau), $\mathrm{CH}$ de Cholet (Dr Aireau), CHU de Nantes (Dr Winer), Maison de naissance, St Sébastien/Loire (Dr Berlivet), 
CHUd'Angers (Dr Gilard) - Picardie: Coordinator: Pr Gondry: CHU d'Amiens (Pr Gondry), Clinique Sainte Claire, Amiens (Dr Degroote), CHG de Beauvais (Dr Manela), CHG de Creil (Dr Cesbron), CHG de Laon (Dr Boury), CHG de Saint Quentin (Dr Closset), CHG de Soissons (Dr Abboud) - Région Poitou-Charentes: Coordinator: Pr Pierre: CHU de Poitiers (Pr Pierre), Clinique du Fief de Grimoire, Poitiers (Dr Bascou), CHG de Niort (Dr Breheret), CHG d'Angoulême (Dr Tariel), CHG de la Rochelle (Dr Quentin), Clinique Sainte Anne, Châtellerault (Dr Boisselier), CHG de Châtellerault (Dr Godard), CHG de Bressuire (Dr Villemonteix), CHG de Saintes (Dr Trousselle) - Région Provence Alpes Côtes d'Azur: Coordinator: Pr D'Ercole: CHU la Conception, Marseille (Dr Agostini), CHR de Draguignan (Dr Diquelou), CHR de Hyères (Dr Eymery), CHR de la Ciotat (Dr Pechikof), CHU Hôpital Nord, Marseille (Pr D'Ercole), CHR de Salon de Provence (Dr Maldiney), CHR de la Seyne sur Mer (Dr Joly) - Région Rhône-Alpes Lyon: Coordinator: Dr Vaudoyer: CHU l'Hôtel Dieu, Lyon (Dr Vaudoyer), CHU la Croix Rousse, Lyon (Pr Gaucherand), CHU Lyon Sud, Lyon (Dr Coste) - Région Rhône-Alpes Grenoble: Coordinator: Dr Vendittelli: CHU Nord et Sud, Grenoble (Dr Vendittelli), Clinique Belledone, Saint Martin d'Hères (Dr Benbassa), Clinique des Cédres, Grenoble (Dr Boschetto), Clinique Mutualiste, Grenoble (Dr Leger), CHU de Saint Etienne (Dr Collet), CH de Bourg en Bresse (Dr Frobert), $\mathrm{CH}$ d'Alberville (Dr Dardenne), CH de Chambéry (Dr Houman), CH d'Annecy (Dr Bernardi), CH de Valence (Dr Broussard), CH de Roanne (Dr Gaja), CH d'Evian les Bains et de Thonon les Bains (Dr Thery), CH de Saint Julien en Genevois (Dr Tognelli), CH de Firminy (Dr Albersammer). 
Table 1: Characteristics, obstetric practices, and maternal and neonatal outcomes for the study population

\begin{tabular}{|c|c|}
\hline Characteristics & Total population $(\mathrm{N}=3330)$ \\
\hline $\begin{array}{l}\text { Maternal age in years }(\text { mean+/-SD) } \\
\begin{aligned}- & <25 \text { years }(\mathrm{n}, \%) \\
- & 25-35 \text { years } \\
- & 35 \text { years }\end{aligned}\end{array}$ & $\begin{array}{l}27.3+/-4.7 \\
994(30.1) \\
2107(63.9) \\
197(6.0)\end{array}$ \\
\hline $\begin{array}{l}\text { Maternal birth place }(\mathrm{n}, \%) \\
-\quad \text { France } \\
\text { - } \quad \text { Abroad }\end{array}$ & $\begin{array}{c}2577(82.9) \\
531(17.1)\end{array}$ \\
\hline $\begin{array}{l}\text { Gestational age in weeks (mean+/-SD) } \\
\begin{aligned}- & 37-38 \text { weeks }(\mathrm{n}, \%) \\
- & 39-40 \text { weeks } \\
- & \geq 41 \text { weeks }\end{aligned}\end{array}$ & $\begin{array}{l}39.5+/-1.2 \\
660(19.8) \\
1996(59.0) \\
702(21.1)\end{array}$ \\
\hline $\begin{array}{c}\text { Onset of labour }(\mathrm{n}, \%) \\
-\quad \text { spontaneous } \\
-\quad \text { induction }\end{array}$ & $\begin{array}{c}2815(84.5) \\
515(15.5)\end{array}$ \\
\hline $\begin{array}{l}\text { Oxytocin during labour }(\mathrm{n}, \%) \\
-\quad \text { yes } \\
-\quad \text { no } \\
-\quad \text { missing }\end{array}$ & $\begin{array}{l}2074(62.3) \\
635(19.1) \\
621(18.6)\end{array}$ \\
\hline $\begin{array}{l}\text { Mode of delivery }(\mathrm{n}, \%) \\
\begin{aligned}- & \text { spontaneous vaginal delivery } \\
- & \text { assisted vaginal delivery }\end{aligned}\end{array}$ & $\begin{array}{l}2529(76.0) \\
801(24.0)\end{array}$ \\
\hline Severe postpartum haemorrhage (n, \%) & $69(2.1)$ \\
\hline Postpartum maternal fever $>48 \mathrm{~h}$ or endometritis (n, \%) & $22(0.7)$ \\
\hline 3rd-4th degree perineal tear $(\mathrm{n}, \%)$ & $52(1.6)$ \\
\hline $\begin{array}{c}\text { Birth weight in grams (mean+/-SD) } \\
-\quad<3000 \mathrm{~g}(\mathrm{n}, \%) \\
-\quad 3000-3499 \mathrm{~g} \\
-\quad 3500-3999 \mathrm{~g} \\
-\quad \geq 4000 \mathrm{~g}\end{array}$ & $\begin{array}{l}3289+/-406 \\
761(22.9) \\
1567(47.2) \\
834(25.1) \\
159(4.8)\end{array}$ \\
\hline
\end{tabular}




\begin{tabular}{|l|c|}
\hline Arterial $\mathrm{pH} \leq 7.10 *(\mathrm{n}, \%)$ & $46(1.4 \%)$ \\
\hline 5-minute Apgar score $\leq 7(\mathrm{n}, \%)$ & $33(1 \%)$ \\
\hline Neonatal trauma $(\mathrm{n}, \%)$ & $50(1.5 \%)$ \\
\hline Admission to NICU (n, \%) & $23(0.7 \%)$ \\
\hline
\end{tabular}

SD: standard deviation

* Only 1088 available data 
Table 2: Association between the duration of different phases and stages of labour and severe PPH

\begin{tabular}{|c|c|c|c|}
\hline Duration & $\begin{array}{c}\text { Severe PPH } \\
\mathrm{N}=69\end{array}$ & $\begin{array}{l}\text { Control } \\
\mathrm{N}=3261\end{array}$ & $\mathrm{p}$ \\
\hline $\begin{array}{l}\text { Between } 5 \text { and } 10 \mathrm{~cm} \text {, in hours (median } \\
\text { [IQ]) }\end{array}$ & $2.5[1.5-3.9]$ & $2.7[1.4-4.7]$ & $0.279 \dagger$ \\
\hline - Less than $2 \mathrm{~h}(\mathrm{n}, \%)$ & $19(31.7)$ & $876(29.6)$ & \\
\hline - $\quad$ Interval 2-4 h & $19(31.7)$ & $1345(45.5)$ & \\
\hline - Interval 4-6 h & $15(25.0)$ & $563(19.0)$ & \\
\hline - $\quad$ More than $6 \mathrm{~h}$ & $7(11.7)$ & $175(5.9)$ & $0.076 \$$ \\
\hline $\begin{array}{l}\text { Passive second stage, in minutes (median } \\
\text { [IQ]) }\end{array}$ & 30 [10-60] & $30[10-60]$ & $0.391 \dagger$ \\
\hline - $\quad$ Less than $60 \min (\mathrm{n}, \%)$ & $44(66.7)$ & $2234(71.3)$ & \\
\hline - $\quad$ Interval 60-120 min & $16(24.2)$ & $647(20.7)$ & \\
\hline - $\quad$ More than $120 \mathrm{~min}$ & $6(9.1)$ & $252(8.0)$ & $0.710 \%$ \\
\hline $\begin{array}{l}\text { Active second stage, in minutes (median } \\
{[\mathrm{IQ}] \text { ) }}\end{array}$ & $20[15-31]$ & 15 [10-25] & $<0.001 \uparrow$ \\
\hline - $\quad$ Less than $10 \min (\mathrm{n}, \%)$ & $6(8.8)$ & $477(15.0)$ & \\
\hline - $\quad$ Interval 10-19 min & $23(33.8)$ & $1378(43.2)$ & \\
\hline - Interval 20-29 min & $16(23.5)$ & $756(23.7)$ & \\
\hline - Interval 30-39 min & $11(16.2)$ & $415(13.0)$ & \\
\hline - $\quad$ Interval 40-49 min & $6(8.8)$ & $128(4.0)$ & \\
\hline - More than $50 \mathrm{~min}$ & $6(8.8)$ & $36(1.1)$ & $<0.001 \ddagger$ \\
\hline
\end{tabular}

IQ: interquartile

$\dagger$ Mann-Whitney test

† Chi2 test 
Table 3: Rates of severe PPH according to mode of delivery and duration of the active second stage

\begin{tabular}{|c|c|c|c|c|}
\hline & \multicolumn{2}{|c|}{ Spontaneous Vaginal Delivery } & \multicolumn{2}{c|}{ Operative Vaginal Delivery } \\
\hline & Total (n) & PPH (n, \%) & Total (n) & PPH (n, \%) \\
\hline Active second stage & & & 60 & \\
- Less than 10 min & 423 & $6(1.4)$ & 254 & $6(2.4)$ \\
- Interval 10-19 min & 1147 & $17(1.5)$ & 202 & $4(2.0)$ \\
- Interval 20-29 min & 570 & $12(2.1)$ & 168 & $4(2.4)$ \\
- Interval 30-39 min & 258 & $7(2.7)$ & 70 & $4(5.7)$ \\
- Interval 40-49 min & 64 & $2(3.1)$ & 21 & $4(19.1)$ \\
- More than 50 min & 21 & $2(9.5)$ & & 0.006 \\
\hline p & & 0.093 & & \\
\hline
\end{tabular}


Table 4: Factors associated with severe PPH - univariable and multivariable analysis

\begin{tabular}{|c|c|c|c|}
\hline & $\begin{array}{l}\text { Severe PPH } \\
\mathrm{N}=69 \mathrm{n}(\%))\end{array}$ & $\begin{array}{l}\text { Crude OR } \\
{[95 \% \mathrm{CI}]}\end{array}$ & $\begin{array}{l}\text { Adjusted OR } \\
{[95 \% \mathrm{CI}]}\end{array}$ \\
\hline \multicolumn{4}{|l|}{ Gestational age } \\
\hline - 37-38 weeks $(n=660)$ & $8(1.2)$ & 1 & 1 \\
\hline - 39-40 weeks $(n=1966)$ & $38(1.9)$ & $1.6[0.7-3.5]$ & $1.6[0.7-3.7]$ \\
\hline - 41-24 weeks $(n=704)$ & $23(3.3)$ & $2.8[1.2-6.2]$ & $1.9[0.7-4.8]$ \\
\hline \multicolumn{4}{|l|}{ Birth weight } \\
\hline$-\quad<3000 \mathrm{~g}(\mathrm{n}=761)$ & $9(1.2)$ & 1 & 1 \\
\hline - $\quad 3000-3499 \mathrm{~g}(\mathrm{n}=1567)$ & $30(1.9)$ & $1.6[0.8-3.5]$ & $1.0[0.5-2.3]$ \\
\hline - $\quad 3500-3999 \mathrm{~g}(\mathrm{n}=834)$ & $26(3.1)$ & $2.7[1.3-5.8]$ & $1.6[0.7-3.6]$ \\
\hline$-\quad \geq 4000 \mathrm{~g}(\mathrm{n}=159)$ & $4(2.5)$ & $2.2[0.7-7.1]$ & $0.6[0.1-3.0]$ \\
\hline \multicolumn{4}{|l|}{ Onset of labour } \\
\hline - $\quad$ Spontaneous $(\mathrm{n}=2815)$ & $51(1.8)$ & 1 & 1 \\
\hline - Induced $(n=515)$ & $18(3.5)$ & $2.0[1.1-3.4]$ & $1.5[0.8-3.0]$ \\
\hline \multicolumn{4}{|l|}{ Mode of delivery } \\
\hline - $\quad$ Spontaneous $(\mathrm{n}=2529)$ & $47(1.9)$ & 1 & 1 \\
\hline - $\quad$ Assisted $(\mathrm{n}=801)$ & $22(2.8)$ & $1.5[0.9-2.5]$ & $1.2[0.7-2.1]$ \\
\hline \multicolumn{4}{|l|}{ Duration from 5 to $10 \mathrm{~cm}$} \\
\hline - $\quad$ Less than 2 h $(n=895)$ & $19(2.1)$ & $1.5[0.8-2.9]$ & $1.8[0.95-3.5]$ \\
\hline - $\quad$ Interval 2-4 h $(n=1364)$ & $19(1.4)$ & 1 & 1 \\
\hline - $\quad$ Interval 4-6 h $(n=578)$ & $15(2.6)$ & $1.9[1.0-3.7]$ & $1.7[0.9-3.4]$ \\
\hline - $\quad$ More than $6 \mathrm{~h}(\mathrm{n}=182)$ & $7(3.9)$ & $2.8[1.2-6.8]$ & $2.5[1.0-6.1]$ \\
\hline \multicolumn{4}{|l|}{$\begin{array}{l}\text { Duration from } 10 \mathrm{~cm} \text { to beginning of } \\
\text { expulsive efforts }\end{array}$} \\
\hline - $\quad$ Less than $1 \mathrm{~h}(\mathrm{n}=2278)$ & $44(1.9)$ & 1 & \\
\hline - Interval 1-2 h $(\mathrm{n}=663)$ & $16(2.4)$ & $1.3[0.7-2.2]$ & \\
\hline - $\quad$ More than 2 h $(n=258)$ & $6(2.3)$ & $1.2[0.5-2.9]$ & \\
\hline \multicolumn{4}{|l|}{ Duration of expulsive efforts } \\
\hline - $\quad$ Less than $10 \min (n=483)$ & $6(1.2)$ & 1 & 1 \\
\hline - Interval 10-19 $\min (n=1401)$ & $23(1.6)$ & $1.3[0.5-3.3]$ & $1.3[0.5-3.5]$ \\
\hline - $\quad$ Interval 20-29 $\min (\mathrm{n}=772)$ & $16(2.1)$ & $1.7[0.7-4.3]$ & $1.7[0.6-4.8]$ \\
\hline - Interval 30-39 $\min (\mathrm{n}=426)$ & $11(2.6)$ & $2.1[0.8-5.7]$ & $1.9[0.6-5.7]$ \\
\hline - $\quad$ Interval 40-49 $\min (\mathrm{n}=134)$ & $6(4.5)$ & $3.7[1.2-11.7]$ & $3.5[1.0-12.3]$ \\
\hline - $\quad$ More than $50 \min (n=42)$ & $6(14.3)$ & $13.2[4.1-43.2]$ & $10.6[2.8-40.3]$ \\
\hline
\end{tabular}


References

1. Cheng YW, Hopkins LM, Caughey AB. How long is too long: Does a prolonged second stage of labor in nulliparous women affect maternal and neonatal outcomes? Am J Obstet Gynecol 2004;191(3):933-8.

2. Janni W, Schiessl B, Peschers U, Huber S, Strobl B, Hantschmann P, et al. The prognostic impact of a prolonged second stage of labor on maternal and fetal outcome. Acta Obstet Gynecol Scand 2002;81(3):214-21.

3. Menticoglou SM, Manning F, Harman C, Morrison I. Perinatal outcome in relation to second-stage duration. Am J Obstet Gynecol 1995;173(3 Pt 1):906-12.

4. Moon JM, Smith CV, Rayburn WF. Perinatal outcome after a prolonged second stage of labor. J Reprod Med 1990;35(3):229-31.

5. Myles TD, Santolaya J. Maternal and neonatal outcomes in patients with a prolonged second stage of labor. Obstet Gynecol 2003;102(1):52-8.

6. Saunders NS, Paterson CM, Wadsworth J. Neonatal and maternal morbidity in relation to the length of the second stage of labour. Br J Obstet Gynaecol 1992;99(5):381-5.

7. Rouse DJ, Weiner SJ, Bloom SL, Varner MW, Spong CY, Ramin SM, et al. Secondstage labor duration in nulliparous women: relationship to maternal and perinatal outcomes. Am J Obstet Gynecol 2009;201(4):357 e1-7.

8. Buhimschi CS, Buhimschi IA, Malinow AM, Kopelman JN, Weiner CP. Pushing in labor: performance and not endurance. Am J Obstet Gynecol 2002;186(6):1339-44.

9. Le Ray C, Audibert F, Goffinet F, Fraser W. When to stop pushing: effects of duration of second-stage expulsion efforts on maternal and neonatal outcomes in nulliparous women with epidural analgesia. Am J Obstet Gynecol 2009;201(4):361 e1-7. 
10. Goffinet F, Carayol M, Foidart JM, Alexander S, Uzan S, Subtil D, et al. Is planned vaginal delivery for breech presentation at term still an option? Results of an observational prospective survey in France and Belgium. Am J Obstet Gynecol 2006;194(4):1002-11.

11. Le Ray C, Carayol M, Zeitlin J, Breart G, Goffinet F. Level of perinatal care of the maternity unit and rate of cesarean in low-risk nulliparas. Obstet Gynecol 2006;107(6):126977.

12. Le Ray C, Zeitlin J, Jarreau PH, Breart G, Goffinet F. The influence of level of care on admission to neonatal care for babies of low-risk nullipara. Eur J Obstet Gynecol Reprod Biol 2009;144(1):21-6.

13. Modalités de surveillance foetale pendant le travail. Texte des recommandations. J Gynecol Obstet Biol Reprod (Paris) 2008(37S):S101-S107.

14. Le Ray C, Audibert F. [Duration of pushing in labor: literature review]. J Gynecol Obstet Biol Reprod (Paris) 2008;37(4):325-8.

15. Naime-Alix AF, Fourquet F, Sigue D, Potin J, Descriaud C, Perrotin F. [How long can we wait at full dilatation. A study of maternal and neonatal morbidity related to the duration of the second stage of labour in nulliparous women]. J Gynecol Obstet Biol Reprod (Paris) 2008;37(3):268-75.

16. Fraser WD, Marcoux S, Krauss I, Douglas J, Goulet C, Boulvain M. Multicenter, randomized, controlled trial of delayed pushing for nulliparous women in the second stage of labor with continuous epidural analgesia. The PEOPLE (Pushing Early or Pushing Late with Epidural) Study Group. Am J Obstet Gynecol 2000;182(5):1165-72.

17. Plunkett BA, Lin A, Wong CA, Grobman WA, Peaceman AM. Management of the second stage of labor in nulliparas with continuous epidural analgesia. Obstet Gynecol 2003;102(1):109-14. 
18. Vause S, Congdon HM, Thornton JG. Immediate and delayed pushing in the second stage of labour for nulliparous women with epidural analgesia: a randomised controlled trial. Br J Obstet Gynaecol 1998;105(2):186-8.

19. Roberts CL, Torvaldsen S, Cameron CA, Olive E. Delayed versus early pushing in women with epidural analgesia: a systematic review and meta-analysis. Bjog 2004;111(12):1333-40.

20. Allen VM, O'Connell CM, Baskett TF. Maternal and perinatal morbidity of caesarean delivery at full cervical dilatation compared with caesarean delivery in the first stage of labour. Bjog 2005;112(7):986-90.

21. Alexander JM, Leveno KJ, Rouse DJ, Landon MB, Gilbert S, Spong CY, et al. Comparison of maternal and infant outcomes from primary cesarean delivery during the second compared with first stage of labor. Obstet Gynecol 2007;109(4):917-21.

22. Blondel B, Supernant K, Du Mazaubrun C, Breart G. [Trends in perinatal health in France between 1995 and 2003: results from the National Perinatal Surveys]. J Gynecol Obstet Biol Reprod (Paris) 2006;35(4):373-87.

23. Menacker F, Martin JA. BirthStats: rates of cesarean delivery, and unassisted and assisted vaginal delivery, United States, 1996, 2000, and 2006. Birth 2009;36(2):167.

24. Combs CA, Murphy EL, Laros RK, Jr. Factors associated with postpartum hemorrhage with vaginal birth. Obstet Gynecol 1991;77(1):69-76. 